\title{
IMMUNOSUPPRESSION IN TOXOPLASMOSIS: FURTHER STUDIES ON MICE INFECTED WITH LOUPING-ILL VIRUS
}

\author{
H. W. Reid, D. Buxton, I. Pow and J. Finlayson \\ Animal Diseases Research Association, Moredun Institute, 408 Gilmerton Road, \\ Edinburgh EH17 7JH
}

\begin{abstract}
MICE with acute toxoplasmosis are more susceptible to louping-ill virus than mice infected with virus alone; however, the susceptibility of mice infected with virus when the toxoplasma infection has reached the chronic stage is not increased (Buxton et al., 1980). A study of infection with another protozoan, Trypanasoma brucei, showed that parasite-induced immunosuppression profoundly altered the course of louping-ill virus infection in mice (Reid et al., 1979). The aim of the present study was to examine in more detail the effect of acute toxoplasmosis in mice upon subsequent infection with louping-ill virus.
\end{abstract}

\section{MATERIALS AND METHODS}

Mice. Random-bred Swiss-white mice 4-5 weeks old were used.

Toxoplasma gondii. Inocula were prepared from the brains of mice infected with the M1 strain of T. gondii at the third brain pass (Buxton, Reid and Pow, 1979) and mice were infected as described by Buxton et al. (1980). Control inocula were prepared in the same way from the brains of uninfected mice.

Virus. The SB526 strain of louping-ill virus was used at the second passage in suckling mice and the inoculum was prepared (Reid and Doherty, 1971) and injected as already described (Buxton et al., 1980). Control inocula were prepared similarly from uninfected mouse brain.

Experiments. To examine the effect of $T$. gondii infection on the development of virus and antibody titres and on encephalitis, the following experiment was performed. On day -7 , each of 250 mice was given an injection of $T$. gondii (group 1) and 250 were given an injection of the control inoculum (group 2); all 500 were given louping-ill virus on day 0 . A further 50 mice (group 3) were given an injection of $T$. gondii on day -7 and control inoculum on day 0 . Mice in each group were numbered sequentially and all mice that died were discarded. The first 20 live mice in groups 1 and 2 were killed on day 2 , and a further 20 on each of days $4,6,8$ and 10 while 20 mice from group 3 were killed on days 2 and 10 . All surviving mice were discarded.

Collection and examination of samples. Blood for virus and antibody assay was collected in heparin-coated capillary tubes. Brains were removed and halved longitudinally; one half was placed in a polyethylene bag and stored at $-70^{\circ} \mathrm{C}$ pending virological examination and the other in $10 \%(\mathrm{v} / \mathrm{v})$ formol-saline. Spleens were removed, placed in polyethylene bags and stored at $-70^{\circ} \mathrm{C}$.

Virus and antibody assays were performed and fixed half-brains were processed, stained and the perivascular cuffs counted and expressed as cuffs $/ \mathrm{cm}^{2}$ as described by Buxton et al (1980).

Statistical analysis. Results from the groups were compared by the two-tailed Mann-Whitney $U$-Test for figures of a non-parametric distribution.

\section{RESULTS}

On day 2 there was more circulating virus in the mice infected with only louping-ill virus than in the dually infected mice $(\mathrm{p}<0.05)$ but thereafter very little virus was detected in the former 


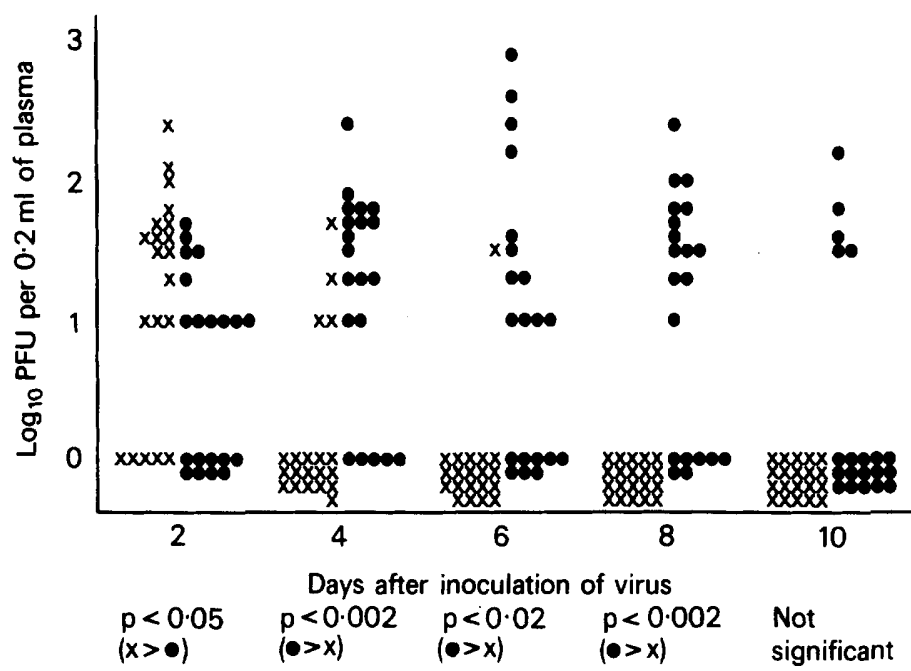

FIG. 1.-Titre of louping-ill virus in plasma of mice given either louping-ill virus alone $(x)$ or Toxoplasma gondii and louping-ill virus ( $\bullet$; each symbol point represents the result from one mouse. PFU =plaque forming units. The significance of difference between the groups is shown beneath the results for each day of testing.

animals while levels in the latter group rose significantly and remained high for 6 days (fig. 1). By day 10 there was no difference between groups.

Titres of virus recovered from spleens (fig. 2) were similar until day 4 but on days 6,8 and 10 they were higher in the dually infected mice.

Brains from both groups yielded no virus on day 2, approximately equal amounts on day 4 and 6 , but on days 8 and 10 more virus was present in the dually infected mice (fig. 3 ).

Haemagglutination inhibiting (HI) antibody was not detected until day 6 when half the mice infected with virus alone had antibody compared with one in the dually infected group $(p=<0.02)$ (fig. 4). By day 10 most of the former group had developed antibody but only three from the dually infected group had done so $(p=<0.002)$.

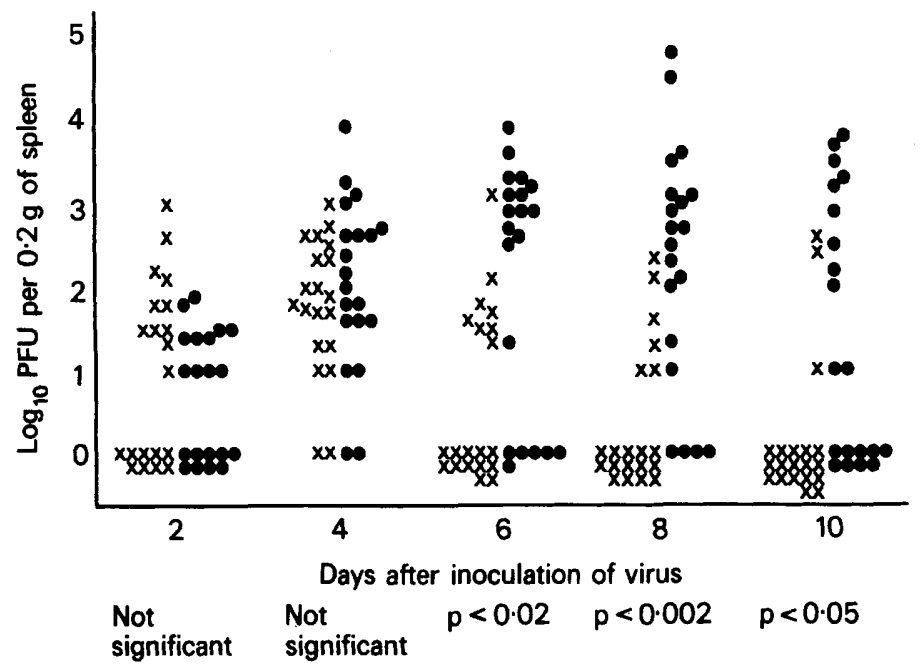

FIG. 2.-Titre of louping-ill virus in spleen of mice given either louping-ill virus alone or $T$. gondii and louping-ill virus. Symbols as in fig. 1. 


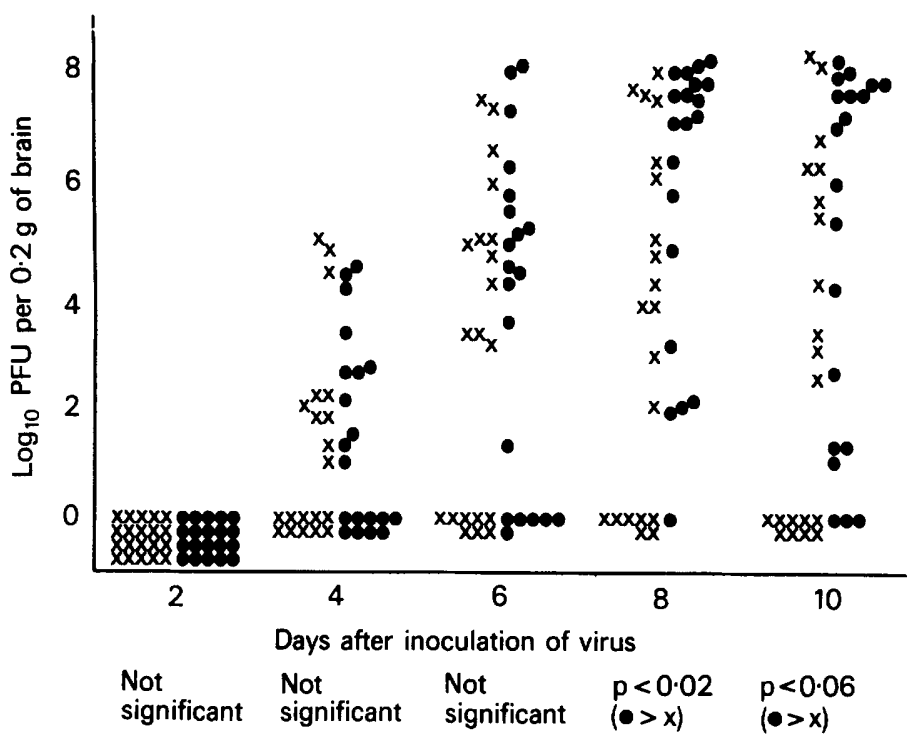

FIG. 3.-Titre of louping-ill virus in brain of mice given either louping-ill virus alone or $T$. gondii and louping-ill virus. Symbols as in fig. 1.

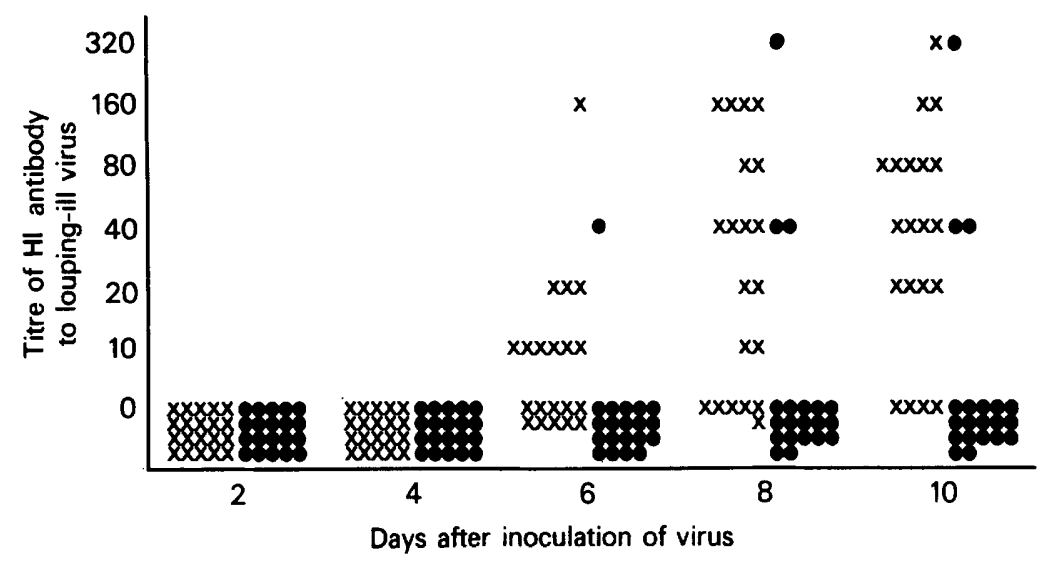

FIG. 4.-Titre of louping-ill virus haemagglutination inhibiting (HI) antibody in plasma of infected mice with louping-ill virus alone or $T$. gondii and louping-ill virus. Symbols as in fig. 1 . 


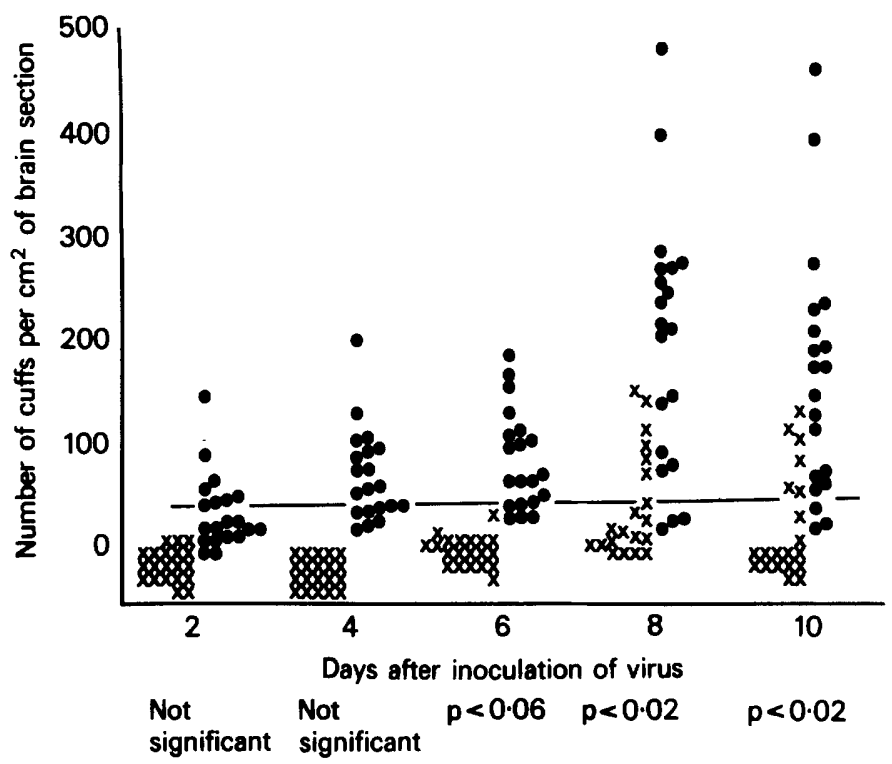

Fig. 5.-Degree of inflammation (number of perivascular cuffs) seen in the brain of mice infected with louping-ill virus alone or $T$. gondii and louping-ill virus. The numbers of perivascular cuffs in mice infected with $T$.gondii alone are indicated by the horizontal line. Symbols as in fig. 1 .

Louping-ill virus was not isolated from any of the tissues taken from the mice injected only with $T$. gondii and $\mathrm{HI}$ antibody to louping-ill virus was not detected in this group at any time.

Neuropathological changes in this experiment were similar to those described by Buxton $e t$ al. (1980). Mice infected with both agents consistently showed a greater inflammatory response in the brain than mice infected only with virus, this difference being most marked on days 8 and 10 (fig. 5). However, because infection with $T$. gondii alone produced a low level of inflammation, the real differences between the two groups given virus were smaller; the significance levels shown in fig. 5 take this into account.

Spleen weights of mice infected with $T$. gondii were greater than those of mice infected only with virus (table).

TABLE

Mean weights of spleen of mice infected with Toxoplasma gondii and louping-ill virus separately or together

\begin{tabular}{|c|c|c|c|c|c|}
\hline \multirow{2}{*}{$\begin{array}{l}\text { Treatment (day of } \\
\text { infection) }\end{array}$} & \multicolumn{5}{|c|}{ Mean weights* of spleens $( \pm S E)$ on indicated day of experiment } \\
\hline & 2 & 4 & 6 & 8 & 10 \\
\hline $\begin{array}{lr}\text { Tox (-7) } & \text { L-ill (O) } \\
\text { C (-7) } & \text { L-ill (O) } \\
\text { Tox (-7) } & \text { C (O) }\end{array}$ & $\begin{array}{l}0.51( \pm 0.02) \\
0.20( \pm 0.01) \\
0.45( \pm 0.02)\end{array}$ & $\begin{array}{c}0.51( \pm 0.02) \\
0.24( \pm 0.01) \\
\ldots\end{array}$ & $\begin{array}{c}0.51( \pm 0.03) \\
0.19( \pm 0.01) \\
\ldots\end{array}$ & $\begin{array}{c}0.46( \pm 0.04) \\
0.18( \pm 0.01) \\
\ldots\end{array}$ & $\begin{array}{l}0.40( \pm 0.05) \\
0.19( \pm 0.02) \\
0.41( \pm 0.03)\end{array}$ \\
\hline
\end{tabular}

* Means from groups of 20.

Tox $=$ Toxoplasma gondii $\mathrm{L}$-ill = louping ill virus; $\mathrm{C}=$ control inoculum.

\section{Discussion}

We have already shown that mice infected with louping-ill virus 7 days after the administration of $T$. gondii display a delayed but significantly greater mortality than mice given virus alone (Buxton et al., 1980). These observations together with the findings reported in this paper 
are similar to those observed in studies of acute viral encephalitis in immunologically compromised hosts (Camenga, Nathanson and Cole, 1974; Chaturvedi, Tandon and Mathur, 1977). Immunosuppression induced by $\gamma$-irradiation (Webb et al., 1968) and cyclophosphamide (Semenov et al., 1975) affects the course of infection with Langat virus which, like louping-ill virus, is a member of the tick-borne-encephalitis complex, in a fashion similar to that in which $T$. gondii affected louping-ill virus infection in this study. Mortality was delayed but increased, viraemias were of greater magnitude and duration, antibody production was depressed and mice died with little evidence of paralysis, normally a characteristic of both virus infections. However, one notable difference was that inflammation in the brains of mice infected with Toxoplasma and louping-ill virus was increased while inflammation in the brains of the immunosuppressed mice infected with Langat virus was minimal.

Reid, Doherty and Dawson (1971) concluded that in louping ill of sheep the perivascular inflammatory cells released virus-specific antibody which was critical for the animal's survival, but Doherty and Vantsis (1973) held that the build up of inflammatory cells itself could contribute to the onset of neurological symptoms. These findings are in accord with the concept that the immune response in viral encephalitis has a dual role (Nathanson et al., 1975). However in the present study mice infected with $T$. gondii and louping-ill virus developed an inflammatory response in the brain more pronounced and rapid than that in mice given virus alone and, in contrast to what might have been expected, the onset of neurological symptoms was delayed and a greater proportion of mice died.

In experimental allergic encephalomyelitis, cells accumulating in the central nervous system are mostly newly formed short-lived lymphocytes (Smith and Waksman, 1969; Werdelin and McCluskey, 1971; Stohl and Gonatas, 1978) and although there is some evidence that specifically sensitised cells may be required to initiate the inflammatory reaction (Werdelin and McClusky, 1971) this has not been found invariably (Stohl and Gonatas, 1978). Whether initiation requires specifically sensitised cells or not, subsequent recruitment is non-specific. The mechanism by which dually infected mice in the present study developed a rapid and pronounced encephalitis despite an impaired antibody response may therefore be as follows.

Toxoplasma infection of mice rapidly stimulates the lymphoreticular system with a resultant enlargement of spleen and lymph nodes and an increased number of circulating small lymphocytes (Huldt, Gard and Olovson, 1973; Henry and Beverley, 1976). Thus in the dually infected mice virus would have been inoculated after the lymphoreticular system had already been considerably stimulated by the $T$.gondii infection. Virus-induced changes in the brain attracted increased numbers of reactive lymphoid cells but because a large proportion of these cells were probably Toxoplasma specific rather than virus-specific, little virus-specific antibody was secreted and virus-infected neurones may have survived longer. Thus uninhibited viral replication eventually resulted in delayed but more extensive virus-induced neuronal damage and hence a delayed but increased mortality (Buxton et al., 1980)

Immunosuppression was held to have been responsible for the effect of infection with another protozoan, Trypanosoma brucei, on the course of louping-ill virus infection in mice (Reid et al., 1979). In these studies, too, the viral infection was markedly increased in severity, with more virus in blood and tissues, more severe encephalitis and increased though delayed mortality. Parasite-induced immunosuppression, which has been shown to operate in some protozoan infections (Schwab, 1975) may therefore be a mechanism by which the susceptibility of man and animals to virus infection is increased.

Whatever the mechanism involved, $T$. gondii is clearly capable of substantially altering the ability of mice to cope with an acute viral infection. $T$. gondii and louping-ill virus frequently infect sheep; the increased susceptibility to the virus, observed in mice after infection with Toxoplasma, may be a factor in increasing the severity of louping ill in some sheep.

\section{SUMMARY}

Mice were infected with an avirulent cyst-producing strain of Toxoplasma gondii and given injections of louping-ill virus 7 days later; control mice were given virus but not Toxoplasma. Test and control mice were then killed, in groups, $2,4,6,8$ and 10 days later. In the dually 
infected mice viraemia was later, greater and more prolonged; titres of virus recovered from brain and spleen were greater; production of haemagglutinating antibody to louping-ill virus was later and less, and inflammation in the brain was more severe, than in mice given virus alone. We suggest that $T$. gondii suppressed the immunity of mice, making them more susceptible to the virus, and that a significant proportion of the increased number of inflammatory cells observed in the brain could have been toxoplasma specific and not virus-specific and hence contributed to the increased susceptibility of the dually infected mice to louping-ill virus.

\section{REFERENCES}

Buxton, D., Reid, H. W., Finlayson, J. AND Pow, I. (1980). Immunosuppression in toxoplasmosis: preliminary studies in mice infected with louping-ill virus. J. comp. Path. (In press).

Buxton, D., ReID, H. W. AND Pow, I. (1979). Immunoppression in toxoplasmosis: studies in mice with a clostridial vaccine and louping-ill virus vaccine. J. comp. Path., 89, 375.

Camenga, D. L., Nathanson, N. and Cole, G. A. (1974). Cyclophosphamide-potentiated West Nile viral encephalitis: relative influence of cellular and humoral factors. J. infect. Dis., 130, 634.

Chaturvedi, U. C., Tandon, P. ANd Mathur, A. (1977). Effect of immunosuppression on dengue virus infection in mice. J. gen. Virol., 36, 449.

DohERTY, P. C. AND VANTSIS, J. T. (1973). Louping-ill encephalomyelitis in the sheep. VII. Influence of immune status on neuropathology. J. comp. Path., 83, 481.

HeNRY, L. AND BEVERLEY, J. K. A. (1976). The response of the mouse R-E system to infection with Toxoplasma gondii. Virchows Arch. Abt. B., cell Path., 20, 55.

HuldT, G., GARD, S. AND Olovson, S. G. (1973). Effect of Toxoplasma gondii on the thymus. Nature, Lond., 244, 301.

Nathanson, N., Johnson, E. D., Camenga, D. L. and Cole, G. A. (1975). Immunosuppression and experimental viral infection: the dual role of the immune response. In The immune system and infectious diseases. 4th International Convocation on Immunology, Buffalo, NY, 1974, edited by E. Neter and F. Milgram. Karger: Basel, p. 76.

Reid, H. W., Buxton, D., Finlayson, J. and Holmes, P. H. (1979). Effect of chronic Trypanosoma brucei infection on the course of louping-ill virus infection in mice. Infect. Immun., 23, 192.

REID, H. W. AND DoHeRTy, P. C. (1971). Experimental louping-ill in sheep and lambs. I. Viraemia and the antibody response. J. comp. Path., 81, 291.

ReID, H. W., DoherTy, P. C. AND DAwson, A. MCL. (1971). Louping-ill encephalomyelitis in the sheeping. III. Immunoglobulins in cerebrospinal fluid. J. comp. Path., 81, 537.

SCHWAB, J. H. (1975). Suppression of the immune response by microorganisms. Bact. Rev. 39, 121.

Semenov, B. F., VARgin, V. V., ZsChiesche, W., AND Veckenstedt, A. (1975). Influence of certain immunodepressants on experimental flavivirus and enterovirus infections in mice. Intervirology, 5, 220.

Smith, S. B. AND WaKsman, B. H. (1969). Passive transfer and labelling studies on the cell infiltrate in experimental allergic encephalomyelitis. J. Path., 99, 237.

Stohl, W. and Gonatas, N. K. (1978). Chronic permeability of the central nervous system to mononuclear cells in experimental allergic encephalomyelitis in the Lewis rat. J. Immunol., 121,844 .

Webb, H. E., Wight, D. G. D., Wiernik, G., Platt, G. S. ANd Smith, C. E. G. (1968). Langat virus encephalitis in mice. II. The effect of irradiation. J. Hyg., Camb., 66, 355.

WERDELIN, O, AND MOClUSKEY, R. T. (1971). The nature and the specificity of mononuclear cells in experimental autoimmune inflammation and the mechanisms leading to their accumulation. J. exp. Med., 133, 1242. 